\title{
Kiedy dyskusja przeradza się w spór - różne odsłony programów telewizyjnych o charakterze publicystycznym w sztuce wymiany myśli i wywierania nacisków. Ujęcie genologiczne
}

Przede wszystkim potrzeba wiedzieć, o czym się mówi, albo cała dyskusja na nic, bezwarunkowo. A ludzie po większej części nie wiedzą nawet o tym, że nie znają istoty każdej rzeczy. A jednak tak, jak gdyby ją znali, nie porozumiewają się co do tego na początku rozważań, toteż w dalszym toku za to pokutują. Bo ani się sami z sobą potem, ani z drugimi pogodzić mogą ${ }^{1}$.

Z dolność porozumiewania się za pomocą mowy czyni człowieka istotą wyjątkową. Nie oznacza to jednak, że wraz z nabyciem umiejętności werbalizowania przekazów posiadł on także kompetencje komunikacyjne - te bowiem użytkownicy języka zdobywają stopniowo na drodze socjalizacji. Aby językowe obcowanie rozmówców mogło przynieść satysfakcję każdej ze stron, muszą zostać spełnione określone warunki, wśród których należałoby wymienić: konkretność rozmówców, wzajemną otwartość i szacunek parterów względem siebie, akceptację ról społecznych, szczerość i prawdomówność, a także gotowość wzięcia odpowiedzialności za swoje słowa ${ }^{2}$. Przywołane przez katowickie

\footnotetext{
"Dr Aleksandra Katarzyn Kalisz - Instytut Języka Polskiego, Uniwersytet Śląski w Katowicach, e-mail: o.kalisz@gmail.com, ORCID: 0000-0003-3696-1535.

1 Platon, Fajdros, tłum. W. Witwicki, Kąty 2002, s. 18.

2 R. Piętkowa, B. Witoszowa, Kryzys rozmowy jako sygnat przeobrażeń modelu językowych interakcji, w: Przemiany wspótczesnej polszczyzny. Materiały konferencji naukowej. Opole 20-22.09.1993 r., red. S. Gajda, Z. Adamiszyn, Opole 1994, s. 198.
} 
badaczki kryteria pozostają jednak coraz częściej w przestrzeni idealizacji. Komunikacja, zawierająca w swej definicji równe traktowanie uczestników danego spotkania, przyjmuje bowiem postać działań czysto egocentrycznych, odchodząc tym samym od proponowanego przez Jürgena Habermasa ujęcia racjonalności komunikacyjnej, którego celem nadrzędnym jest dochodzenie do porozumienia ${ }^{3}$. W obliczu dyskusji i sporów, jakich wiele w przestrzeni życia prywatnego czy publicznego, wzniosłe idee mogą posłużyć jedynie za wzorzec dobrych praktyk komunikacyjnych. Wszak nietrudno dostrzec na co dzień wśród uczestników rozmów wyraźną chęć zyskania hegemonii, w konsekwencji prowadzącej do zachowań antagonistycznych ${ }^{4}$. Nic więc dziwnego, że sporadycznie występujące w parze partnerstwo i komunikacja przestają nosić znamiona pleonazmu, wzajemnie się dopełniając.

Niezwykła złożoność sytuacji komunikacyjnej, wynikająca z jej nieprzewidywalności, a ściślej postawy uczestników danego zdarzenia komunikacyjnego, stała się motywacją do podjęcia badań genologicznych nad dwoma gatunkami mowy - dyskusją i sporem, które zdają się ujawniać swoją osobliwość zarówno w przestrzeni życia codziennego, jak i w telewizji. Oba typy tekstów, występujące w programach publicystycznych, cechuje swoista indywidualność genologiczna, co przejawia się nie tylko w naprzemiennym adaptowaniu swoich komponentów, lecz także w zależności od potrzeb elementów innych, pokrewnych gatunków mowy. W pierwszej kolejności podejmę próbę ustalenia wzorca gatunkowego dwóch przywołanych konstrukcji, by następnie uchwycić moment, w którym dyskusja przeradza się w spór. Istotne będzie także zweryfikowanie pola tematycznego sprzyjającego przechodzeniu jednego gatunku w drugi. Analizę dopełni przegląd sytuacji komunikacyjnych, do jakich dochodzi w programach telewizyjnych „Warto rozmawiać” i „Kawa na ławę”, które coraz częściej zachodzące w studiu zdarzenia określają mianem rozmowy, wykluczając tym samym ich sporny charakter.

\section{Dyskusja a spór w rozważaniach semantycznych}

Na wstępie warto sięgnąć do słowników w celu ustalenia różnic między rozmową, dyskusją, sporem i kłótnią - w moim przekonaniu pojęciami kluczowymi dla dalszych rozważań. Pierwsze z nich stanowi swoistą kanwę, na której wyrastają pozostałe. Rozmowa, jak podkreślają katowickie badaczki,

3 J. Habermas, Pojęcie działania komunikacyjnego, tłum. A. M. Kaniowski, „Kultura i Społeczeństwo" 1986, t. XXX, nr 3, s. 42.

4 M. Steciąg, Trudna sytuacja komunikacyjna - spotkanie z Innym (na przykładzie reportażu Kosy i dredy z ,Gazety Wyborczej”), w: Sytuacja komunikacyjna i jej parametry. I monografia z cyklu Sytuacje - Komunikacja - Konteksty, red. G. Sawicka, Bydgoszcz 2010, s. 279. 
mogłaby być uznana za gatunek wypowiedzi, dysponujący określonymi regułami budowy, które mogą być rozmaicie realizowane w zależności od tzw. składników sytuacyjnych aktu mowy: charakterystyki socjalnokulturowej rozmówców, ich kompetencji komunikacyjnej, wzajemnej relacji partnerów, miejsca spotkania, tematu i innych okoliczności. Miałaby więc rozmowa realizacje bardziej skonwencjonalizowane (np. dyskusja, wywiad, negocjacje) i takie, których reguły strukturalne i pragmatyczne rysują się mniej wyraźnie, jak np. rozmowa potoczna, sprzeczka, kłótnia, pogaduszki, paplanina ${ }^{5}$.

Dyskurs, w jakim realizowana jest rozmowa, będzie miał zatem istotny wpływ na jej kształt. Owa 'ustna wymiana myśli' (SWJP) czy 'dłuższa wymiana zdań pomiędzy co najmniej dwiema osobami, zwłaszcza w sytuacji nieoficjalnej' (ISJP) może przyjmować rozmaite formy, których punktem wspólnym będzie spotkanie z Drugim. Czym zatem rozmowa różni się od dyskusji? Inny słownik języka polskiego definiuje ją jako 'wymianę zdań na jakiś temat przebiegającą w sposób uporządkowany, zwykle mającą doprowadzić do wspólnych wniosków' (ISJP). Ważną kwestię jedności między dyskutantami można upatrywać we 'wspólnym omawianiu, rozpatrywaniu jakiegoś zagadnienia' (SJP). Dyskusja jawi się więc jako forma przemyślana, niespontaniczna, tę cechę bowiem skłonni jesteśmy przypisać rozmowie. Będzie ją także wyróżniać mniej formalny charakter spotkań. Subtelne różnice między rozmową a dyskusją są wyraźniejsze w zestawieniu $\mathrm{z}$ formułami definiującymi Anny Wierzbickiej. Badaczka rozmowę sprowadza do wzajemnej wymiany myśli. Przytaczane przez nią „różne rzeczy”, które wypowiadają rozmówcy, dzieją się za obopólną zgodą naprzemiennie ${ }^{6}$. W przypadku dyskusji jest zgoła inaczej:

\footnotetext{
Sądzę, że ty myślisz co innego o X niż ja.

Mówię: ...

Mówię to, bo chcę, żeby każdy z nas powiedział, co o tym myśli i dlaczego.

Sądzę, że i ty chcesz, żeby każdy z nas powiedział, co o tym myśli i dlaczego.

Sądzę, że mówiąc to, moglibyśmy spowodować, że będziemy myśleć to samo.

Chciałbym, żebyśmy myśleli to samo.
}

Pierwsza formuła definiująca zakłada przypuszczalną rozbieżność myśli interlokutorów. Dalsza część pozostawia jednak przestrzeń na wzajemną otwartość, co może prowadzić do porozumienia, wykluczając tym samym spór. Ten z kolei bazuje na z góry poczynionych założeniach, a jego uczestnicy stosują wobec siebie różne formy nacisku, uznając za słuszne wyłącznie swoje racje:

5 R. Piętkowa, B. Witoszowa, Kryzys rozmowy, s. 197-198.

6 A. Wierzbicka, Genry mowy, w: Tekst i zdanie. Zbiór studiów, red. T. Dobrzyńska, E. Janus, Wrocław 1983, s. 131.

7 Tamże, s. 131. 
Wiem, że ty myślisz co innego o X niż ja.

Sądzę, że ty myślisz źle.

Mówię: ...

Mówię to, bo chcę, żebyś myślał tak samo jak ja

Wspomniany nacisk wyraźnie wiąże się z narzuceniem swojej wizji świata, negując punkt widzenia rozmówcy.

Słowniki języka polskiego wyraźnie podkreślają konfliktowy charakter sporu. Jest on traktowany jako 'nieporozumienie i dyskusja wynikła z niezgodności poglądów, zdań na jakiś temat' (SWJP). Spór w znacznym stopniu bazuje na dyskusji, jednak zamyka uczestników spotkania na dialog, niebezpiecznie przybliżając ich do kłótni. Wszelkim próbom wyjaśnienia motywacji, jaką kierują się rozmówcy, towarzyszą silne emocje. Kłótnię od sporu różni jednak werbalne wyrażenie tego, co wcześniej znajdowało się w przestrzeni myśli nadawcy. Ujawnienie się sprzecznych stanowisk uczestników spotkania może wywołać niepohamowany potok słowny obu stron, który w najlepszym wypadku prowadzi do całkowitego zerwania porozumienia. Okoliczności, w jakich dochodzi do tego kryzysowego momentu, sprawiają, że 'gwałtowna, ostra wymiana zdań [...] kończy się często obrazą słowną bądź rękoczynem’ (SWJP). Ogniwem zapalnym staje się zanegowanie wizji świata Drugiego i jednoczesne wymuszanie na nim przyznania się do niewłaściwego pojmowania danej rzeczy, co wyraźnie obrazują formuły definiujące Wierzbickiej:

Wiem, że ty myślisz co innego o X niż ja.

Mówię: ty myślisz źle

Mówię to, bo chcę, żebyś powiedział, że mówiłeś źle?.

Aby przekonać się, czy dyskusja i spór są przez współczesnych użytkowników języka rodzimego traktowane jako byty rzeczywiście niezależne, przeprowadziłam badanie ankietowe wśród studentów Wydziału Filologicznego Uniwersytetu Śląskiego. W ankiecie wzięło udział 65 studentów w wieku od 19 do 24 lat. Zadaniem respondentów było zbudowanie krótkiej definicji obu gatunków, a następnie podanie trzech przymiotników je określających. Przytoczone definicje wyraźnie różnicują oba typy tekstów. Jedno, co łączy wspomniane gatunki, to inne spojrzenie na poruszane kwestie. Mamy więc do czynienia z reprezentacją odmiennych poglądów, która w zależności od przebiegu negocjacji między uczestnikami aktu komunikacyjnego będzie przyjmowała postać jednej z omawianych form. Respondenci dostrzegają w dyskusji nić porozumie-

\footnotetext{
8 Tamże, s. 131.

9 A. Wierzbicka, Genry mowy, s. 131.
} 
nia i otwartość na odmienną wizję świata Drugiego. Istotnymi komponentami jest wzajemny szacunek i kultura towarzysząca określonej liczbie rozmówców. Niemałe znaczenie odgrywa jednak przygotowanie do tej formy wypowiedzi poparte argumentami każdej ze stron. Gotowość negocjowania znaczeń ${ }^{10}$ zostaje zatem silnie sprzężona $\mathrm{z}$ tą formą tekstu. Wyklucza ją z kolei spór, zakładający brak porozumienia konflikt o zabarwieniu emocjonalnym. I choć sama dyskusja nie jest pozbawiona dynamizmu, to po stronie sporu respondenci upatrują szereg negatywnych uczuć. Wśród nich znalazły się: wrogość, agresja i niechęć. Przywołane doznania wyłączają racjonalne działania adwersarzy, niejako wymuszając zamknięcie się na argumenty Drugiego i silne skupienie na własnych racjach. Świadczą o tym najczęściej wymieniane przymiotniki: „emocjonalny”, „burzliwy”, „negatywny”, „głośny”, „agresywny”, „zacięty”, „bezsensowny”, „konfliktowy”, „ostry”, „chaotyczny”. Ankietowani zwracali również uwagę na czas trwania sporu. Jego krótki, acz wybuchowy charakter oddawali za pomocą porównań: szybki jak błyskawica, niekontrolowany jak pocisk. Podawane przymioty dyskusji wskazują z kolei na jej pozytywny wydźwięk. Kojarzy się jednak nie tylko z czymś dobrym, lecz także osadzonym w pewnych społecznych ramach. Dyskusja postrzegana jest bowiem jako: kulturalna, merytoryczna, spokojna, rzeczowa, otwarta, swobodna, argumentacyjna, ciekawa, konstruktywna, konkretna, dynamiczna, kompromisowa, opanowana, racjonalna, żywa, pozytywna, neutralna, owocna, ożywiona.

Jak się więc okazuje, intuicyjnie łatwo jest odróżnić dyskusję od sporu. Nietrudno jednak o przekroczenie granicy między przywołanymi gatunkami. Wiele zależy bowiem od postawy samych rozmówców względem sytuacji komunikacyjnej, w której się znaleźli.

\section{Dyskusja i spór w ujęciu genologicznym}

Próby uchwycenia genologicznych wyznaczników dyskusji i sporu są sprawą tylko z pozoru prostą. To, w jaki sposób potoczy się dana rozmowa w znacznym stopniu zależy od jej uczestników. Niewinna konwersacja może bowiem przerodzić się w zażarty spór, podczas gdy w innej sytuacji, z innymi uczest-

10 Pojęcie negocjowania znaczeń uznaję za B. Kudrą i A. Kudrą jako „,w pełni uświadamianą działalność konceptualizacyjną, mającą na celu ustalenie nowych sensów dla istniejących już lub wykreowanych nowych pojęć - zgodnie z określonym punktem widzenia [...]. Negocjowanie znaczeń zakłada w pełni uświadomione działania sensotwórcze, tj. w przemyślanych aktach konceptualizacji. Kreacja pojęciowa, charakterystyczna dla tak pojmowanej negocjacji znaczeń, ma na celu nominacyjne bądź aksjologiczne uzgadnianie sensów w danej sytuacji komunikacyjnej”" (B. Kudra, A. Kudra, Znaczenie, sens, negocjowanie znaczeń - o „ambisemicznym” charakterze konceptualizacji, Acta Universitatis Lodziensis. Kształcenie Polonistyczne Cudzoziemców 2014, nr 21, s. 11-22). 
nikami i zupełnie na inny temat pozostanie tylko merytorycznie przeprowadzoną dyskusją. Jedno jest pewne, wszystkie tego typu realizacje mocno wiąże osoba Drugiego. Nieodzownym elementem dalszych rozważań będzie więc wykorzystanie narzędzi wypracowanych przez Marię Wojtak ${ }^{11}$. Mam tu na myśli szeroko opisane przez badaczkę aspekty: strukturalny, pragmatyczny, poznawczy i stylistyczny, które pozwolą nie tylko lepiej zrozumieć mechanizmy funkcjonowania obu gatunków, lecz także umożliwią zbadanie ich specyfiki w przestrzeni audiowizualnego medium.

Sygnały delimitacyjne, które w pierwszej chwili można dostrzec w dyskusji i sporze, stanowią szkielet wielu innych gatunków ${ }^{12}$. Przy założeniu, że rozmówcom danego spotkania towarzyszy jeden cel - dążenie do wspólnego porozumienia, ramą delimitacyjną obudowującą ożywioną wymianę zdań będzie powitanie i pożegnanie. Te prymarne gatunki mowy ${ }^{13}$ zostają więc wypełnione rozmową, od przebiegu której będzie zależało zakończenie spotkania. Niespodziewane przerodzenie się sporu w kłótnię może zagrozić bowiem całkowitemu zerwaniu aktu komunikacyjnego, co tym samym wpłynie na kształt wskaźnika finalnego tekstu.

Istotnym elementem należącym do omawianego aspektu strukturalnego jest również paratekst - tekst okalający tekst właściwy. Rozmowę, dyskusję i spór będą więc napędzały wszelkiego rodzaju przekazy zaczerpnięte z otoczenia, w którym żyją potencjalni partnerzy rozmowy. Zróżnicowanie tych trzech gatunków zostanie więc uzależnione od doboru i sposobu wykorzystania wcześniej przyjętych tekstów w czasie przebiegającej wymiany myśli między „ty” i „ja”. O ile inspirację do rozmowy będą stanowiły wszelkie komunikaty o charakterze neutralnym dla samych partnerów komunikacji, o tyle w przypadku dyskusji czy sporu to ładunek emocjonalny będzie odgrywał kluczową rolę w kształtowaniu się ich formy. Jak się więc okazuje, to, co różnicuje dyskusję od sporu w pewnym stopniu znajduje swoje odzwierciedlenie w aspekcie strukturalnym. Wyraźniejszych rozbieżności między oboma gatunkami należy jednak poszukiwać w kolejnych aspektach wzorca gatunkowego.

Niezbędne dla ustalenia tego, czym są analizowane zdarzenia i w jaki sposób dochodzi do przekraczania ich wzajemnych granic, będzie wytyczenie celu komunikacyjnego każdego z tych gatunków, choć, jak się okazuje, to

11 M. Wojtak, Wyznaczniki gatunkowe zapowiedzi, w: Nowe media. Nowe w mediach, red. I. Borkowski, A. Woźny, Wrocław 2001, s. 53-67.

M. Wojtak, Wyznaczniki gatunkowe komentarza prasowego, w: Tekst w mediach, red. K. Michalewski, Łódź 2002, s. 372-386.

м. Wojtak, Wzmianka jako gatunek wypowiedzi prasowej, w: Język polski. Współczesność. Historia, red. W. Książek-Bryłowa, H. Duda, t. IV, Lublin 2003, s. 161-174.

12 A. Kalisz, O roli plotki w mediach masowych i nie tylko. Ujęcie genologiczne, [w druku].

13 M. Bachtin, Estetyka twórczości słownej, tłum D. Ulicka, Warszawa 1986, s. 351. 
zadanie wcale niełatwe ${ }^{14}$. Zgodnie z przywołanymi formułami Wierzbickiej i słownikowymi definicjami, dyskusja ma doprowadzić do znalezienia wspólnej płaszczyzny porozumienia, ustalenia znaczeń w obrębie jakiegoś tematu różnicującego dyskutantów. Oczywiście to cel nadrzędny. Pobocznymi zaś mogą być: zgłębienie wiedzy, wzajemne wysłuchanie się uczestników danego zdarzenia czy nawet chęć zaspokojenia kontaktu $\mathrm{z}$ drugim. W przypadku sporu cel będzie dwufazowy - w pierwszej kolejności wywarcie nacisku na odbiorcę, a następnie skłonienie go do przyjęcia punktu widzenia nadawcy. Aby każdy z przywołanych gatunków mógł zaistnieć w konkretnym miejscu i czasie, wymaga wsparcia ze strony innego, na którego kanwie jest możliwe zrealizowanie określonych celów komunikacyjnych. Tym sposobem rozmowa staje się miejscem narodzin dyskusji, a ta $\mathrm{z}$ kolei, w znacznie emocjonujących warunkach, przyjmuje postać sporu. Przyczyną przejścia jednego gatunku w drugi jest jednak nie tylko określona postawa względem innych rozmówców, w tym także konkretna intencja przyświecająca poszczególnym uczestnikom, ale przede wszystkim ujawnienie się przyjętego i wyznawanego przez nich systemu wartości. Punkt widzenia może bowiem okazać się sprzeczny z poglądami pozostałych członków aktu komunikacyjnego, co w skrajnych przypadkach prowadzi do sporu. Niezwykle ważnym elementem rozgraniczającym oba gatunki jest więc wachlarz tematyczny. Nie wszystko, co rozmówcy chcą powiedzieć, prowadzi do wzajemnego ubogacenia. Są pewne tematy, które ze swej natury budzą silne emocje, co doskonale obrazują programy telewizyjne o nachyleniu publicystycznym. Odmienne przekonania zostają tu wykorzystane do zręcznego balansowania między gatunkami opartymi na rozmowie. $\mathrm{W}$ rezultacie widz ma do czynienia z dyskusją, która niepostrzeżenie przeradza się w spór, którego finał przybiera rozmaite formy. W przestrzeni telewizyjnej, w swojej najbardziej zaskakującej postaci, może bowiem zakończyć się ostentacyjnym opuszczeniem studia przez jednego z rozmówców, choć z pewnością to nie jedyny scenariusz niespodziewanych rozstrzygnięć tego typu spotkań, jakie mogą zakładać programy o charakterze publicystycznym.

To, czy ostatecznie spotkanie przyniesie obopólną korzyść i zakończy się wspólnym uzgodnieniem znaczeń, będzie zależało od wzajemnego szacunku. „Stąd nadawca, mówiąc, winien mieć na uwadze prawo odbiorcy do zmiany ról komunikacyjnych"15. Nadmierne eksponowanie „ja”, stylistyka wypowiedzi opierająca się na wyrazistości, której rezultatem jest zmiana rejestru języka $\mathrm{z}$ neutralnego na emocjonalny, a także wszelkie strategie niegrzeczności ${ }^{16}$,

14 B. Witosz, Genologia lingwistyczna. Zarys problematyki, Katowice 2005, s. 170.

15 R. Piętkowa, B. Witoszowa, Kryzys rozmowy, s. 200.

16 E. Tyc, Nieestetyczne zachowania jako technika autoprezentacji w mediach masowych, w: Estetyka językowa w komunikowaniu. Prace dedykowane profesorowi Marianowi Bugajskiemu, red. M. Steciąg, M. Kaczor, Zielona Góra 2019, s. 152. 
zamykają na dialog, przyjmując tym samym bardziej skonwencjonalizowane realizacje rozmowy.

\section{Nieszablonowe rozmowy w telewizyjnych programach publicystycznych}

Telewizja to przestrzeń dla różnego rodzaju aktów mownych niezwykle dwuznaczna. Z jednej strony za pośrednictwem rozmaitych widowisk chętnie eksponuje wszelkie zachowania skandaliczne, wykorzystując do tego celu komponenty omawianych gatunków, z drugiej zaś kamufluje ślady ich użycia. Dostrzec to można nie tylko w programach chętnie wykorzystujących rozmowę w swoich tytułach („INFORozmowa” w TVP Info, „Rozmowa bardzo polityczna” w TVN24, „Rozmowa dnia” w TVP Info, „Rozmowa Jedynki” w TVP1, „Rozmowa Rymanowskiego” w TVN24 i „Warto rozmawiać” w TVP), lecz także w postawie gości i prowadzących, którzy toczące się dyskusje i spory określają właśnie mianem rozmowy. Zamiarem owej strategii jest zjednanie sobie widza, który intuicyjnie w tej formie przekazu będzie poszukiwał tego, co mniej oficjalne, jemu bliższe, a tym samym wykraczające poza sferę publiczną ${ }^{17}$.

Przykładem tak zaplanowanego działania jest analizowany przeze mnie program telewizyjny „Warto rozmawiać” nadawany przez stację TVP18. Zawarta w tytule widowiska rozmowa w wielu sytuacjach stanowi zaledwie pretekst do podjęcia trudnych, często kontrowersyjnych tematów dotyczących życia społecznego. Jednak nie tylko tematyka ma wpływ na kształt poszczególnych odcinków, przyczyniają się do tego także gospodarz programu i goście mający niekiedy odmienne spojrzenie na świat. Na potrzeby niniejszego artykułu analizie poddałam pięć losowo wybranych odcinków ukazujących się od stycznia do grudnia 2018 roku. Jednak ze względu na obszerny materiał tekstowy zawarte tu przykłady pochodzą z dwóch wydań programu ${ }^{19}$.

Struktura magazynu w dużej mierze opiera się na wywiadzie. Prowadzący (w tej roli Jan Pospieszalski) przedstawia temat spotkania, a następnie zadaje pytania swoim gościom. W sposób wyraźny tym samym zostaje podkreślona jego rola moderatora. Konwencję wywiadu szybko jednak przełamują narastające głosy rozmówców, co również nie pozostaje bez wpływu na postawę gospodarza, który stopniowo ujawnia swoje stanowisko w omawianej sprawie. Goście niekiedy zabierają głos inspirowani następującymi po sobie replikami, co momentami wymyka się prowadzącemu spod kontroli. Na tym etapie spotkanie przyjmuje postać quasi-dyskusji, w której ukonstytuowana wyłącznie na potrzeby pro-

17 M. Kita, Polski dyskurs prywatności, „Postscriptum Polonistyczne” 2013, nr 1 (11), s. 101.

18 Program nadawano w latach 2004-2011, a następnie wznowiono jego emisję w 2016 roku.

19 Zaprezentowany w materiał pochodzi z odcinków wyemitowanych 18 stycznia i 4 czerwca 2018 roku. 
gramu wspólnota rezygnuje ze wzajemnego porozumienia na rzecz wyraźnie eksponowanego „ja” każdego z uczestników. Taka postawa prowadzi z kolei do wielogłosowości wypowiedzi, które narastając w drodze licznych nawiązań, zaczynają realizować własne cele ${ }^{20}$. Stanowczość, z jaką rozmówcy wypowiadają swoje zdanie, przy jednoczesnym negowaniu poglądów pozostałych członków aktu komunikacyjnego, nie tylko bezpośrednio prowadzi do sporu, lecz także przyczynia się do wyłonienia dyskusyjnego lidera.

Przykład tego typu wypowiedzi można odnotować w odcinku, w którym rozmówcy poruszają kwestię gotowości państwa polskiego na przyjęcie imigrantów oraz postawy Kościoła katolickiego wobec uchodźców z Bliskiego Wschodu. Co ciekawe, zaproszeni do programu goście ${ }^{21}$ reprezentują podobny system wartości, różni ich jednak odmienny sposób podejścia do omawianego tematu:

1. $[\ldots]$

Paulina Guzik: To jest dokładnie to, o czym mówi papież Franciszek: przyjęcie, integracja i asymilacja...

Prowadzący: Dobrze, ale w minioną niedzielę... Bardzo proszę. (Przerywa wypowiedź ioddaje głos kolejnemu rozmówcy).

Jacek Karnowski: Jednak żebyśmy nie wyrzucali też dorobku 2000 lat cywilizacji chrześcijańskiej i 1000 lat, w przypadku państwa polskiego. Nagle okazuje się, że ta nasza wspólnota, ten nasz kraj, nasza ojczyzna, nasz naród, że to jest właściwie nic niewarte i tak naprawdę trzeba to oddać wszystkim chętnym. No bo też moralnie trudno wyznaczyć granicę, że my, nie wiem, przyjmujemy 10 tys., 100 tys., milion...

Bogumił Łoziński: I to jest ten problem...

Jacek Karnowski: Ja dokończę...

Bogumił Łoziński: ...W którym toczy się debata wewnętrzna chrześcijan. To jest w tej chwili...

Jacek Karnowski: Ja dokończę... Aaa debata, ja rozumiem...

Bogumił Łoziński: To jest ta granica...

Jacek Karnowski: Debata się tak żarliwie toczy, ale tak naprawdę jest to scenariusz powtórzenia nieszczęścia, które przydarzyło się państwom zachodnim, gett. Jeżeli państwa zachodnie sobie z tym nie poradziły, to my też sobie nie poradzimy. Nie wiem, dlaczego, widząc tę przyszłość, wy tak bardzo chcecie tej przyszłości. Bogumile, dziś z "Gościa Niedzielnego" wydrukowałem. 2017 rok. Jakie imiona najczęściej nadawaliśmy dzieciom w Polsce. Dziewczynki - Julia, Zuzanna, Zofia. Chłopcy: Antoni, Jakub, Jan,

20 K. Jachimowska, Tekst jako element komunikatu telewizyjnego (na materiale programów publicystycznych), Łódź 2005, s. 36.

${ }^{21}$ W rozmowie wzięli udział: Bogumił Łoziński (dziennikarz, publicysta „Gościa Niedzielnego"), dr Paulina Guzik (medioznawca Uniwersytetu Papieskiego Jana Pawła II w Krakowie), Jacek Karnowski (redaktor naczelny tygodnika „Sieci”) oraz ks. prof. Paweł Bortkiewicz (teolog Uniwersytetu Adama Mickiewicza w Poznaniu). 
Szymon, Franciszek. No chcesz za 20 lat wydrukować listę, gdzie na pierwszym miejscu będzie Mohammed? No przecież to jest ten scenariusz...

Bogumił Łoziński: Ale Jacek, to jest czysta demagogia, to jest czysta demagogia...

Jacek Karnowski: Macie w pogardzie tak naprawdę doświadczenia, pragmatykę, bezpieczeństwo Polaków...

Bogumił Łoziński: Ale, jakie doświadczenia? Przecież...

Jacek Karnowski: Na tym wam nie zależy.

Paulina Guzik: Ja myślę, że trzeba też...

Bogumił Łoziński: To właśnie, co ty prezentujesz jest ideologią (do Jacka Karnowskiego). Jacek Karnowski: ...I to jest manipulacja Ewangeliami. Gdyby tak czytano Ewangelię, to nie powstałaby cywilizacja chrześcijańska w takiej formie, w jakiej ją teraz mamy.

Bogumił Łoziński: Nasza historia...

Jacek Karnowski: Sobieski nie szedłby pod Wiedeń...

Bogumił Łoziński: Nasza historia Polski właśnie pokazuje to, o czym mówiliśmy...

Jacek Karnowski: ....Bo byście mu zabronili, zabronili...

Bogumił Łoziński: Myśmy przyjmowali ludzi z zewnątrz, myśmy ich integrowali i nawet muzułmanie, Tatarzy, doskonale w naszym społeczeństwie funkcjonują. Ja nie mówię, żeby tu przyjąć miliony...

(Wielogłos uniemożliwiający zrozumienie treści kolejnych replik)

Jacek Karnowski: Przepraszam, to są pastisze! Doświadczenia. Idą masy z Bliskiego Wschodu, a ty je de facto porównujesz do średniowiecza z kilkuset letnim procesem asymilacji z czasów I RP.

Bogumił Łoziński: Nikt nie mówi, żeby te masy przyjmować...

Jacek Karnowski: To jest pastisz!

Bogumił Łoziński: Jacku, nikt nie mówi, żeby te masy przyjmować.

Paulina Guzik: Ale jeśli weźmiemy pod uwagę, ilu mamy...

Prowadzący: Przepraszam...

Paulina Guzik: ...Mieszkańców Ukrainy, którzy są emigrantami ekonomicznymi...

Jacek Karnowski: To jest ten sam krąg kulturowy...

Paulina Guzik: ...To na tej liście powinien się znaleźć llia i Aleksandr, a nie Antonii...

Jacek Karnowski: Paulina, to jest ten sam krąg kulturowy, to jest ten sam krąg kulturowy. Ja zresztą używam tego argumentu w stosunku do ludzi, którzy mówią, że nie należy wpuszczać Ukraińców. Ja im mówię: „Nie chcecie Ukraińców, będziecie mieli ludzi z krajów arabskich". Więc to jest argument nietrafiony, bo to jest ten sam krąg kulturowy.

Prowadzący: Przepraszam, ale...

Jacek Karnowski: Polacy w Wielkiej Brytanii to nie jest to samo, co Arabowie w Polsce. No przepraszam bardzo!

$[\ldots]^{22}$

22 „Warto rozmawiać”, 18.01.2018 r. 
Sygnałem pojawienia się sporu w przywołanym fragmencie polilogu jest zanegowanie stanowiska rozmówcy gwałtownym wtrąceniem własnego zdania. Biorący udział w rozmowie zażarcie bronią swoich racji, czemu towarzyszą silne emocje. Fala narastających zarzutów między uczestnikami spotkania wyraźnie uwydatnia stronę atakującą i atakowaną rozgrywającego się sporu. Uczestnicy w celu wzmocnienia przekazu wykorzystują rozmaite chwyty retoryczne, które wbrew pozorom nie mają za zadanie przekonać nieprzekonanych, lecz nadać językowej wyrazistości rozmowie przebiegającej w studiu. Bohaterowie przytoczonej wymiany zdań chętnie odwołują się więc do autorytetu, jakim dla wszystkich uczestników jest Pismo Święte czy zasłużonych postaci historycznych. Odmienna interpretacja przywołanych fragmentów Biblii, inne spojrzenie na wydarzenia historyczne w konsekwencji prowadzą do konfliktu. Spór błyskawicznie przeradza się zatem w kłótnię, w której poszczególne repliki nakładają się na siebie, tworząc szum komunikacyjny. Napięcie towarzyszące ostrej wymianie zdań drastycznie ucina prowadzący, tym samym zaznaczając swoją obecność nie tylko w postawie moderatora (2), lecz także aktywnego i dociekliwego dyskutanta (3):

2. Paulina Guzik: Ale Polska ma ustawę, która reguluje to, kogo możemy przyjąć, a kogo nie...

(Wielogłos uniemożliwiający zrozumienie treści kolejnych replik)

Prowadzący: Dobrze, pani powtórzyła za papieżem Franciszkiem, że uchodźca ma twarz Chrystusa i jak zapuka do drzwi to trzeba mu otworzyć. Tylko, co zrobimy, kiedy tych chrystusów przychodzi milion i nie pukają do drzwi, tylko je wyłamują? Tym pięknym słowem chciałem ubogacić księży biskupów...

Bogumił Łoziński: Ale Janek, kto chce tu milionów...

Prowadzący: ....i bardzo dziękuję za rozmowę. ${ }^{23}$

3. Prowadzący: Jest z nami pani Iza Karska, Stowarzyszenie Twoja Sprawa. Stowarzyszenie to monitoruje przekroczenia i seksualizację przestrzeni publicznej. Wszelkie łamanie prawa, bo przecież mamy prawo w Polsce, które próbuje jakoś tę sferę, o której mówimy, cywilizować...

Iza Karska: Regulować...

Prowadzący: ...Ograniczać i regulować. Natomiast przypominam sobie w 2013 roku, między innymi Stowarzyszenie Twoja Sprawa było współorganizatorem takiej konferencji w sejmie, która 5 lat temu miała zaangażować polityków, ustawodawców, żeby coś z tym zrobić, bo mamy w Polsce prawo - uwaga - z 1997 roku, które mówi o pornografii.

Iza Karska: To znaczy...

Prowadzący: Co w ciągu 5 lat się zmieniło?

23 „Warto rozmawiać”, 18.01.2018 r. 
Iza Karska: Yyy...

Prowadzący: Od tego czasu, kiedy Stowarzyszenie monitorowało..., jakby alarmowało, że jest niedobrze.

Iza Karska: Cały czas te działania podejmujemy. Przez te 10 lat też obserwujemy, że wiele się zmienia. To nie jest tak, że temat ten jest dalej tematem tabu. On się pojawia i coraz więcej dyskusji. No dowodem na to jest dzisiejsza konferencja i to nasze dzisiejsze spotkanie tutaj. Staramy się docierać szeroko z edukacją do rodziców, tłumacząc im i dając konkretne rozwiązania...

Prowadzący: Dobrze, ale o tym, co staracie się zrobić, to jest bardzo ważne, o tym za chwileczkę, tylko co w ciągu tego pięciolecia się zmieniło z dostępnością, z nasyceniem przestrzeni publicznej?

Iza Karska: No nie da się ukryć, ta seksualizacja jest obecna w reklamie. To, co jest na billboardach, w reklamach, czasopismach, na YouTubie, w ogóle w sieci, jest formą seksualizacji, a pornografia jest ekstremalną formą seksualizacji. To jest proces, który ma sprowadzić postrzeganie nas, siebie jako obiekty seksualne. Stąd też...

Prowadzący: Przepraszam, konferencja...

Iza Karska: ....Nasza rola też w tym, żeby uświadamiać i politykom, i specjalistom różnych dziedzin, jak ten proces przebiega i jak to zachodzi, no właśnie, w świecie reklamy.

Prowadzący: Tak tylko, że pięciolecie w waszej historii, oczywiście to ważny czas, ale dla mnie jako obserwatora tamtej konferencji i dzisiejszej konferencji... Odniosłem takie wrażenie, że rozmawiamy o dwóch różnych epokach. Informatycy, obserwatorzy przestrzeni publicznej, szczególnie rzeczywistości internetowej, powiedzieliby, że to jest, że to jest... epoka kamienia łupanego...

Iza Karska: Przeskok...

Prowadzący: Dostępność internetu, LTE, dostępność smartfonów, ich niska cena... Ostatnio słyszałem: „Smartfon najlepszym prezentem na komunię...

$[\ldots]^{24}$

Mimo rozbieżnych poglądów i napiętej sytuacji panującej podczas omawiania kwestii przyjmowania do Polski uchodźców (1 i 2) uczestnicy nie uciekają się do ostatecznych rozwiązań słownych, lecz próbują dbać o język kreowanych przekazów. Nie oznacza to jednak, że przestrzegają zasad językowej grzeczności. Świadczy o tym chociażby częste łamanie zasady szacunku względem rozmówców ${ }^{25}$, co przejawia się nieustannym wchodzeniem sobie w słowo. Przywołane repliki ujawniają istotną informację na temat relacji, jakie łączą uczestników rozmowy. Zarówno goście, jak i gospodarz programu nie są sobie zupełnie obcy. Świadczą o tym bezpośrednie zwroty do adresata zawarte w formułach inicjujących kontakt. Goszczący w studiu płynnie przechodzą więc na „ty”,

24 „Warto rozmawiać, $4.06 .2018 \mathrm{r}$.

${ }^{25}$ K. Ożóg, Polszczyzna przełomu XX i XXI wieku. Wybrane zagadnienia, Rzeszów 2001, s. 76. 
rezygnując z typowej dla stylu oficjalnego formy pan/pani. Skrócenie dystansu między uczestnikami spotkania uwydatnia się wraz z narastającymi emocjami, potęgowanymi poruszaną tematyką. W ten sposób znana z programów rozrywkowych familiarność przenika także widowiska o nachyleniu publicystycznym.

Wróćmy jeszcze na moment do mownych zachowań prowadzącego magazyn „Warto rozmawiać”. Pospieszalski nie zadaje bowiem wyłącznie pytań swoim gościom, ale wyraźnie eksponuje swój głos w omawianej sprawie: wyraża opinię, podaje pewne zjawiska $\mathrm{w}$ wątpliwość, spiera się $\mathrm{z}$ uczestnikami spotkania. Sposób, $\mathrm{w}$ jaki wchodzi $\mathrm{w}$ interakcję z gośćmi, nie zależy więc od tego, czy omawiana w programie kwestia stanowi zarzewie konfliktu, czy, jak w przypadku rozmowy o przepisach prawnych chroniących młodzież przed internetową pornografią (3), jednoczy zebranych. Postawa dziennikarza ujawnia serię powtarzalnych działań strategicznych, które w pierwszej kolejności przejawiają się w dążeniu do uzyskania określonych informacji zawartych w wiedzy operacyjnej partnerów dyskusji, a następnie zostają skierowane na osobę prowadzącego ${ }^{26}$.

Przykładem innego widowiska o niejednoznacznym rysie genologicznym jest program „Kawa na ławę” nadawany przez stację TVN $24^{27}$. Tym razem wszelkie przebiegające w studiu rozmowy toczą się wokół stołu, przy którym zasiadają politycy różnych frakcji i omawiają najważniejsze wydarzenia mijającego tygodnia. Tak zaplanowana przestrzeń telewizyjnego studia ma stwarzać pozory rodzinnej atmosfery, w której to spotkania zyskują mniej formalny charakter. Tymczasem przy zastawionym stole zaproszeni goście, wywołani do odpowiedzi przez gospodarza programu (w tej roli Konrad Piasecki), wykładają tytułową kawę na ławę w sposób dosadny, nie tyle oskarżając siebie nawzajem, co atakując poglądy frakcji, za którą stoją poszczególni uczestnicy spotkania. Taka sytuacja nie pozostawia przestrzeni na dialog, czego dowodzi wymiana zdań (4) na temat postawy polityków partii rządzącej w związku z obchodami 15. rocznicy wstąpienia Polski do Unii Europejskiej:

4. Prowadzący: Ale to mam pytanie do opozycji. Skoro słyszycie te tony euroentuzjastyczne w obozie rządzącym to przestaniecie mówić o polexicie, no bo rozumiem, że się cieszycie, ale czy przestaniecie mówić o polexicie?

Andrzej Halicki: Cieszyłbym się, tylko tu pan minister Sasin obnażył tą hipokryzję, nawet sam dzisiaj to mówiąc. No właśnie nie chodzi o to, że w czasie uroczystości i święta jest sympatycznie, bo to dosyć oczywiste, że powinno być sympatycznie, zwłaszcza przy okrągłej rocznicy, tylko na co dzień. A na co dzień jest... No tu rozumiem apel prezydenta

26 A. Małyska, Wplyw sytuacji komunikacyjnej na wybór strategii językowych we wspótczesnych programach publicystycznych, w: Sytuacja komunikacyjna i jej parametry. I monografia z cyklu Sytuacje - Komunikacja - Konteksty, red. G. Sawicka, Bydgoszcz 2010, s. 254.

27 Program emitowany jest nieprzerwanie od 2006 r. Od 2018 roku zmianie uległ prowadzący - Bogdana Rymanowskiego zastąpił Konrad Piasecki. 
Dudy do swojego własnego zaplecza. No kto podważa ten interes narodowy, o którym mówił? Jarosław Kaczyński, minister Waszczykowski, premier Szydło, premier Morawiecki później, Legutko, Krasnodębski...

Jacek Sasin: Niech pan pozdrowi Junckera.

Andrzej Halicki: ...Pawłowicz przywołana i tak dalej. Mógłbym wymieniać bez liku. Jacek Sasin: Niech pan pozdrowi Junckera.

Andrzej Halicki:... Prawie wszyscy. Pana też, pana też. (Zwracając się do Jacka Sasina). Jacek Sasin: Junckera niech pan pozdrowi.

Prowadzący: A Juncker jest eurosceptyczny?

Jacek Sasin: Nie, ale Juncker obalił całą waszą narrację o euroexicie...

Andrzej Halicki: Ale to jest...

Jacek Sasin: ... I teraz macie problem.

Andrzej Halicki: Ale jakby pan mógł posłuchać przynajmniej do końca raz, a nie wtrącać się, to by pan usłyszał. Z panem Junckerem prezes Kaczyński powinien się spotkać natychmiast, bo właśnie tam, przy stole, przy wspólnych negocjacjach, mógłby walczyć o pieniądze, o pieniądze dla Polski, które stracił - 100 mld zł. A kogo wy wybieracie jako partnera? Salviniego, który rozwala Unię?

Andrzej Dera: A było tak przyjemnie, panie redaktorze, a było tak przyjemnie i wydawało się, że mamy zgodę do tego, żeby...

Andrzej Halicki: Tak właśnie.

Jacek Sasin: Z Salvinim nie będziemy.

Andrzej Halicki: Ale jak to?

Jacek Sasin: Bo nie miał czasu...

Andrzej Halicki: ... Ale, ale, przepraszam...

(Wielogłos uniemożliwiający zrozumienie treści kolejnych replik)

Jacek Sasin: Ale ja nie miałem czasu sprostować...

Prowadzący: To za chwilę będą sprostowania. Pytanie do pani poseł: Czy narracja o polexicie odchodzi w przeszłość?

(Kieruje kolejne pytanie do Moniki Rosy).

$[\ldots]^{28}$

Analiza pięciu losowo wybranych odcinków ${ }^{29}$ wykazała, że toczące się w programie rozmowy także opierają się na formule wywiadu. Jednak w przeciwieństwie do magazynu „Warto rozmawiać" udzielane przez polityków odpowiedzi stanowią pewnego rodzaju komentarz w danej sprawie. Jego realizacje najczęściej zamiast zinterpretowanej informacji przyjmują postać zarzutów kierowanych pod adresem przeciwników politycznych, które z kolei prowadzą do bezpośredniego sporu między uczestnikami spotkania. Nie trzeba długo czekać, by

28 „Kawa na ławę”, 5.05.2019 r.

29 Badane odcinki zostały wyemitowane między styczniem a majem 2019 roku. 
wyrażona opinia wraz z konkretnymi oskarżeniami względem Drugiego stały się zarzewiem konfliktu. Wymiana zdań między uczestnikami daleka jest więc od merytorycznej dyskusji, a niepohamowane emocje towarzyszące gościom bardziej niż rozmowie sprzyjają narastającym awanturom. Niemałą rolę odgrywa w tym zdarzeniu gospodarz programu, który pojawiające się konflikty próbuje zażegnać. Przywołuje więc rozmówców do porządku, tym samym dbając o to, by każdy mógł odeprzeć zarzuty oponenta. Oprócz postawy dziennikarza--rozjemcy pełni on również funkcję dociekliwego reportera, konfrontującego swoich gości z wcześniej udzielonymi odpowiedziami, czy wypominającego brak zaangażowania w sprawę pedofilii kolejno rządzących partii, jak w podanym fragmecie:

5. Prowadzący: Według raportu Kościoła 382 duchownych po roku 1990 wykorzystywało małoletnich. Niemal 200 z nich wykorzystywało małoletnich poniżej 15 roku życia. Czy panowie rozumiecie, jak to się dzieje, że dzisiaj w więzieniu przebywa zaledwie trzech duchownych, którzy mają wyrok za pedofilię? Bartosz Arłukowicz.

Bartosz Arłukowicz: To rzecz niesłychana jest, dlatego że ten raport jest znany od marca tego roku i właściwie nie widzimy działania, przynajmniej nie słyszymy w sejmie o podjętych działaniach, jeśli takie są, to prosilibyśmy ministra sprawiedliwości o ich ujawnienie, choć miał do tego możliwość w sejmie, my jakoś nie słyszeliśmy tego, ile wszczęto postępowań. To pokazuje, że tak naprawdę dochodzi do zjawiska tuszowania tych spraw, i to jest niezwykle ważna sprawa. Bo jeżeli jest tak, że 382 księży wskazuje sama komisja kościelna w swoim raporcie to znaczy, że tych 382 księży, coś się z nimi wydarzyło. Ja chciałbym powiedzieć, że analizując dokładnie ten raport, o którym rozmawiamy, przerażająca jest jeszcze jedna rzecz, że spośród tych 270 postępowań kanonicznych, które prowadzono wobec księży z problemem pedofilii, tylko 25 proc. zostało wydalonych ze stanu duchowieństwa. A wiecie państwo, ilu do organów państwa księży zostało zgłoszonych przez swoich przełożonych? To są niesłychane dane: 1,3 proc. wszystkich zgłoszonych do instytucji sprawiedliwości, państwowych instytucji, pedofilii wśród księży była zgłoszona przez przełożonych księży, 1,3 proc.

Prowadzący: Panie pośle, tyle, że to jest problem, który nie urodził się w ciągu ostatnich trzech lat.

Bartosz Arłukowicz: Oczywiście.

Prowadzący: To jest problem, jak pokazuje ten raport Kościoła, który w Kościele katolickim trwa od lat. Zapewne w całej historii Kościoła można by takie przypadki znaleźć...

Krzysztof Hetman: Nie tylko w Polsce.

Prowadzący: Mam wrażenie... Tak, zresztą nie tylko w Polsce. To nie jest tak, że od trzech i pół roku ta sprawa jest zamiatana pod dywan i tak naprawdę, jeśli szukamy odpowiedzialnych politycznie, to możemy znajdować ich wśród wszystkich rządzących od lat.

Paweł Pudłowski: Ale nie, nie zgodzę się z tą tezą.

[...] 
Paweł Pudłowski: To znaczy, są dowody na to, że Prawo i Sprawiedliwość nie działa. My jako Nowoczesna złożyliśmy wniosek do prokuratury o możliwości popełnienia przestępstwa, a właśnie dlatego, że raport Episkopatu, który wskazuje 382 przypadki, a tylko trzech zatrzymanych jest jawnym ukrywaniem tej reszty. Co odpisuje nam prokuratura? Odpisuje nam to, że nie widzi podstaw do wszczęcia postępowania, i to jest najlepszy dowód, że państwa sztama z Kościołem jest na tyle duża, żeby chronić te środowiska, a my podkreślamy, że to nie jest atak na Kościół, to jest atak na pedofilię w koloratkach [...]. $[\ldots]^{30}$

Skonfliktowani ze sobą rozmówcy potrafią w niebywały sposób żonglować emocjami, zmieniając swoją postawę względem innych uczestników spotkania w zależności od potrzeby chwili. Przykładem tego są pojawiające się między nadrzędnymi tematami spotkań swoiste przerywniki, ukazujące zupełnie inne relacje między poszczególnymi gośćmi. Chwilowe odejście od spraw konfliktogennych, a tym samym porzucenie formalnych zwrotów adresatywnych, niespodziewanie przekształca spór w niewinną pogawędkę przy okazji 27. Finału Wielkiej Orkiestry Świątecznej Pomocy:

6. Prowadzący: Zachęcam do licytacji godziny gry w squasha ze mną. Jeśli ktoś ma ochotę ze mną zagrać, jeśli ktoś z państwa przy tym stole ma ochotę...

Bartosz Arłukowicz: A ja tylko powiem jako lekarz, że to ciężko będzie wytrzymać...

Prowadzący: Bartosz Arłukowicz będzie mierzył puls tym wszystkim, którzy się odważą... temu szczęśliwcowi, który...

Tadeusz Cymański: 76. Nie jest źle.

Prowadzący: 76 puls?

Tadeusz Cymański: Tak.

Prowadzący: W spoczynku.

Tadeusz Cymański: Myślę, że pan też taki ma. (Do prowadzącego). To jest dobry? (Pytanie kierowane do Bartosza Arłukowicza)

Bartosz Arłukowicz: Bardzo.

Prowadzący: Ja 48.

Bartosz Arłukowicz: Ale Tadeusz, za chwilę ci go podwyższę (śmiech).

Tadeusz Cymański: Już, drodzy państwo, zaczyna się dziać powoli...

(Wielogłos uniemożliwiający zrozumienie treści kolejnych replik)

Prowadzący: Dobrze, przejdźmy więc do polityki... ${ }^{31}$

Ponowne wejście w rolę oponentów, zasygnalizowane przez jednego z uczestników, uwypukla teatralny charakter rozmów o proweniencji politycznej, tym

30 „Kawa na ławę”, 19.05.2019 r.

31 „Kawa na ławę”, 13.01.2019 r. 
samym ukazując telewizję jako kreatora wielu rzeczywistości, którym towarzyszą rozmaite emocje. Wykorzystywane w tym celu gatunki mowy nie są widzowi obce, stanowią bowiem istotną część jego komunikacyjnej codzienności. Struktury gatunkowe użyte w analizowanych programach telewizyjnych zostają jednak poddane swoistej modyfikacji. Przywołane magazyny bez wątpienia bazują na rozmowie, która w tej przestrzeni występuje w postaci kolekcji form gatunkowych. Mamy zatem do czynienia ze szczególnym rodzajem sytuacji komunikacyjnej, która w zależności od celu spotkania, intencji rozmówców oraz konwencji samego programu będzie ulegała swoistym przeobrażeniom. Oznacza to, że w jednej chwili może przyjąć postać dyskusji, by za moment przekształcić się w spór, a innym razem w kłótnię. Tak opracowany na potrzeby telewizji konglomerat gatunków ma charakter efemeryczny i otwarty ${ }^{32}$, co sprawia, że za sprawą dowolnie następujących po sobie form dochodzi do przeformułowania intencji mówiącego. Ten bowiem niemal natychmiast zakłada inny punkt widzenia Drugiego, by w dalszej kolejności zarzucić mu niewłaściwy tok rozumowania, co można by zawrzeć w następujący sposób:

Wiem, że ty myślisz co innego o X niż ja.

Sądzę, że ty myślisz źle.

Mówię: ty myślisz źle

Mówię to, bo chcę, żebyś wiedział, że to ja mam rację.

Celem tak zaprojektowanej komunikacji jest wyraźne wyeksponowanie ja mówiącego, a ściślej jego racji w danej sprawie. Zanegowanie światopoglądu Drugiego i silna chęć wyrażenia własnych przekonań coraz częściej przyjmuje postać „mówienia obok siebie”33. Rozmówcy przestają bowiem słuchać tego, co mają do powiedzenia pozostali uczestnicy spotkania, pogrążając się w chaosie komunikacyjnym.

Niezwykle szybko narastający konflikt jest tylko dowodem na to, że pewne tematy nie podlegają dyskusji, a wręcz bezpośrednio prowadzą do kłótni. Odmienność światopoglądowa, przynależność do określonej partii czy organizacji nie pozwala bowiem na merytoryczną wymianę zdań. Sprawy kontrowersyjne, sprzeczne z przekonaniami stron rodzą pewne napięcia, które utrudniają znalezienie przestrzeni na inny ogląd danej sprawy. Często nie sposób zgodzić się na proponowane rozwiązania, ponieważ jakikolwiek kompromis niesie za sobą nie tyle zmianę postawy, co ingerencje w tożsamość rozmówców zarówno tę osobistą, jak i społeczną.

32 G. Stachyra, Gatunki audycji w radiu sformatowanym, Lublin 2008, s. 101.

33 M. Kita, Medialna moda na dialog, w: Dialog a nowe media, red. M. Kita, J. Grzenia, Katowice 2004, s. 175. 


\section{Zakończenie}

W idealnym świecie rozmowy i dyskusje przynoszą satysfakcję obustronną. Codzienność nie pozostawia jednak złudzeń, dając temu dowody w postaci niedokończonych wypowiedzi, zażartych sporów, a nawet kłótni. Jednak bez względu na realny przebieg „spotkanie Drugiego zmienia nasz ogląd świata”" Mówi też wiele o samych rozmówcach, a ściślej ich postawie względem pozostałych uczestników aktu komunikacyjnego. Dotychczasowe ustalenia pozwalają spojrzeć na przywołane gatunki z perspektywy skonwencjonalizowanych odsłon rozmowy. Ta jest bowiem swoistą kanwą, która w zależności od relacji między podmiotami komunikacji, celu komunikowania, a także hierarchii wartości wytyczanej przez rozmówców będzie przyjmowała określony kształt. Nie bez znaczenia dla samego zdarzenia komunikacyjnego jest także przestrzeń, w której toczy się określony gatunek mowy. Telewizja sprzyja kreowaniu wyrazistych tekstów. Nic więc dziwnego, że wszelkiego rodzaju dyskusje czy debaty o zabarwieniu politycznym wcześniej czy później przeradzają się w spór. Tocząca się między uczestnikami wymiana zdań zostaje tu w dużej mierze wyreżyserowana, a sprawujący kontrolę nad jej przebiegiem prowadzący w odpowiedni sposób zawiadują czasem antenowym, czego nie sposób sobie wyobrazić w świecie realnym. Niezależnie jednak od miejsca realizowania się rozmowy moment przejścia od dyskusji do sporu po samą kłótnię wyznaczają uczestnicy spotkania w zależności od postawy, jaką prezentują wobec Drugiego.

\section{Literatura}

Bachtin M., Estetyka twórczości słownej, tłum D. Ulicka, Warszawa 1986.

Habermas J., Pojęcie działania komunikacyjnego, tłum. A. M. Kaniowski, „,Kultura i Społeczeństwo” 1986, t. 30, nr 3, s. 21-44.

Jachimowska K., Tekst jako element komunikatu telewizyjnego (na materiale programów publicystycznych), Łódź 2005.

Kalisz A., O roli plotki w mediach masowych i nie tylko. Ujęcie genologiczne, [w druku].

Kita M., Medialna moda na dialog, w: Dialog a nowe media, red. M. Kita, J. Grzenia, Katowice 2004, s. 171-188.

Kita M., Polski dyskurs prywatności, „Postscriptum Polonistyczne” 2013, nr 1 (11), s. 93-103.

Kudra B., Kudra A., Znaczenie, sens, negocjowanie znaczeń - o "ambisemicznym" charakterze konceptualizacji, Acta Universitatis Lodziensis. Kształcenie Polonistyczne Cudzoziemców 2014, nr 21, s. 11-22.

Małyska A.,

Ożóg K., Polszczyzna przełomu XX i XXI wieku. Wybrane zagadnienia, Rzeszów 2001.

Piętkowa R., Witoszowa B., Kryzys rozmowy jako sygnał przeobrażeń modelu językowych interakcji, w: Przemiany współczesnej polszczyzny. Materiały konferencji naukowej. Opole 20-22.09.1993 r., red. S. Gajda, Z. Adamiszyn, Opole 1994, s. 197-202.

34 R. Piętkowa, B. Witoszowa, Kryzys rozmowy, s. 199. 
Platon, Fajdros, tłum. W. Witwicki, Kęty 2002.

Steciąg M., Trudna sytuacja komunikacyjna - spotkanie z Innym (na przykładzie reportażu Kosy idredy

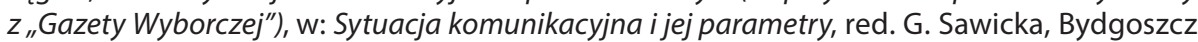
2010 , s. 278-286.

Tyc E., Nieestetyczne zachowania jako technika autoprezentacji w mediach masowych, w: Estetyka językowa w komunikowaniu. Prace dedykowane profesorowi Marianowi Bugajskiemu, red. M. Steciąg, M. Kaczor, Zielona Góra 2019, s. 151-164.

Wierzbicka A., Genry mowy, w: Tekst i zdanie. Zbiór studiów, red. T. Dobrzyńska, E. Janus, Wrocław 1983, s. 125-137.

Witosz B., Genologia lingwistyczna. Zarys problematyki, Katowice 2005.

Wojtak M., Wyznaczniki gatunkowe zapowiedzi, w: Nowe media. Nowe w mediach, red. I. Borkowski, A. Woźny, Wrocław 2001, s. 53-67.

Wojtak M., Wyznaczniki gatunkowe komentarza prasowego, w: Tekst w mediach, red. K. Michalewski, Łódź 2002, s. 372-386.

Wojtak M., Wzmianka jako gatunek wypowiedzi prasowej, w: Język polski. Współczesność. Historia, red. W. Książek-Bryłowa, H. Duda, t. IV, Lublin 2003, s. 161-174.

\section{Skróty:}

ISJP - Inny słownikjęzyka polskiego 2000, M. Bańko.

SJP - Słownik języka polskiego 1978, red. M. Szymczak.

SWJP - Słownik współczesnego języka polskiego 1999, red. S. Dunaj.

\section{Streszczenie}

Znana już w starożytności potrzeba wpływania na rozmówcę, a co za tym idzie, chęć ingerowania w jego światopogląd, nierozerwalnie łączy się z koniecznością eksponowania ,ja” mówiącego, ukazującego własny punkt widzenia. Doskonałym przykładem kreowania swoistej narracji o sobie samym i własnych przekonaniach są współczesne programy publicystyczne emitowane za pośrednictwem audiowizualnych mediów. Celem prezentowanego artykułu jest przebadanie dyskusji i sporu za pomocą narzędzi genologicznych i uchwycenie dychotomii zachodzącej między przywołanymi konstrukcjami. Tak poczyniona analiza pozwoli nie tylko na zweryfikowanie tezy dotyczącej hybrydyzacji obu form, lecz także na ustalenie tego, gdzie w przestrzeni telewizyjnego studia przebiega granica między dyskusją a sporem i jakie czynniki decydują o pojawieniu się jednego z tych gatunków. Końcowym etapem rozważań będzie przyjrzenie się temu, w jaki sposób samo otoczenie, a zatem środek przekazu, może mieć wpływ na omawiane formy.

Słowa klucze: dyskusja, spór, gatunki mowy, programy publicystyczne 


\section{When the discussion turns into a dispute - different versions of television programmes of a journalistic nature in the art of exchanging thoughts and exerting pressure Geneological shot}

\section{Summary}

The need, already known in ancient times, to influence the interlocutor, and thus the desire to interfere in his worldview, is inseparably connected with the necessity to expose the speaking "I", showing its own point of view. A perfect example of creating a kind of narrative about oneself and one's own beliefs are contemporary current affairs programmes broadcast through audio and visual media. The aim of the presented article is to examine the discussion and dispute with the use of genological tools and to grasp the dichotomy between the above-mentioned constructions. Such an analysis will not only allow us to verify the thesis concerning the hybridization of both forms, but also to determine where in the television space of the studio the boundary between discussion and dispute lies and what factors determine the appearance of one of these species. The final stage of the reflection will be to look at how the environment itself, and therefore the media, can influence these forms.

Keywords: discussion, dispute, genres of speech, current affairs programs 